\title{
Słowo na theatrum wojny, czyli mowy pozostałe po czasach Dymitriad. Epizod smoleński
}

Maria Barłowska 


\section{Maria Barłowska}

\section{Słowo na theatrum wojny, czyli mowy pozostałe po czasach Dymitriad. Epizod smoleński}

$\mathrm{R}$ ozpowszechnienie siç oratorstwa w Rzeczypospolitej XVII w. było postrzegane jako jedna z jej cech specyficznych. W tonic wyraźnic pochwalnym, prezentując Europic poczet najznakomitszych mówców sarmackich, Szymon Starowolski pisał o znaczeniu wymowy:

nie widziałem, by gdziekolwiek była szerzej praktykowana. W Polsce bowiem, gdy wśród szlachty ktoś przychodzi una świat lub umiera, schodzą się sąsiedzi i wobec niezwykle licznego grona sluchaczy wyglaszają mowy, czy to winszujące, czy żałobne. Podobnie, gdy świętuje się zaślubiny albo wzywa sklóconych, by powrócili do dawnej przyjaźni. gdy trwa proces sądowy albo ktoś obejmuje urząd, gdy wita się powracających z wojny lub długicj podróży, gdy nad dobrem publicznym obradują sejmiki, gdy posłowie ziemscy wysyłani są na sejm koronny, gdy obiera się sędziów trybunalu w którymkolwiek roku i z.jakiegokolwiek okręgrı — wszędzie tam wygłaszane są oracje ułożone zgodnie z zaleceniami retorów'.

W zupelnic inncj, satyrycznej tonacji, ale w jakżc podobny sposób, rozwijał myśl o rozplenieniu się w Polsce oratorstwa Maciej Kazimicrz Sarbiewski². Dla poparcia wspólıej prze-

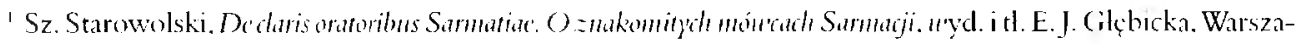
wa 2002, s. 27.

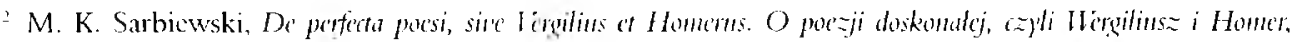
tl. M. Plezia, opr. S. Skimina, Wrodaw 1954. s. 200-201: .Gidzic indzicj nymowa zmajduje schronicnic w książach. 1 nas pantijo ma zchraniach. w sądach. ma scjmach. $[\ldots]$ I'rzy kolysce i przy katafalku, przy stoke i przy slubic. zaw'sze wyghaszajạ mowy pozdrawiaja nimi przychodzącycl na świat. żegnają ode lodzących zeri. synowic ojców dworzanic swych panów wracajacych z niasta witaja przemowami. jakby co najmucj z Indii przybywali".
} 
słanki obydwaj pisarze zastosowali wyliczenia, tworzące długi katalog okoliczności, z którymi związane było wyglaszanie mów. Wydawać by się mogło, żc kiatalog ten, wskazując jako główne obszary funkcjonowania oratorstwa w życiu publicznym sejm, sejmiki i trybunaly, a w życiu prywatnym różne uroczystości i okazje rodzimme, wyczerpuje je niemal calkowicic. I rzeczywiście, ogląd drukowanych zbiorów oratorskich taką ocenę potwierdza. Jednak sięgnięcie do wykladów retoryki każe odnotować jészcze jeden obszar funkcjonowanial oratorstwa ${ }^{3}$. W podbudowanym tradycją antyczną przekonaniu retorów siła wymowy miała objawiać się też na wojnie. Czyżby więc mówca, nie tylko żohnierz, występowal w XVII w. na theatrum wojny?

Związek krasomówstwa i wojny na pewno nie dziwi w epice historycznej. Karty poematów prócz scen batalistycznych wypełniajł relacje z narad i poselstw, a samym starciom towarzyszą wygłaszane przez wodzów i bohaterów bojowe pobudki. Równie oczywiste jest pojawianie się oratorstwa towarzyszącego wojnie w historiografii. Jednak mimo wzmianek wspólczesnych, jak cloćby pochwaly Starowolskiego formulowane wobec żolnierskiej wymowy Jana Zamoyskiego, Stanislawa Źólkiewskiego czy Jana Karola Chodkiewicza, rzeczywiste istnienie tego obszaru oratorstwa pozostawalo jedynie w sferze przypuszczeń. Prześledzenie źródel związanych z oblężeniem Smoléśsk w latach 1609-1611 powinno nadać tym przypuszczeniom bardziej realny ksztalt ${ }^{+}$.

Obraz obozu pod Smoleńskiem, jaki rysuje siç w świetle rękopiśmiennych przekazów, pozwala dostrzec niebagatelną rolę, jaką odegrało na tej scenie wojennej oratorstwo. Już sama liczba wygtoszonych i zachowanych przemów jest znacząca: do dziś odıalazlam ich 16. Przede wszystkim są to mowy poselskie. Tworzą one najliczniejszą reprezentację, co latwo daje się wythumaczyć specyficzną sytuacją. Pod Smoleńskiem przebywal bowiem sam król Zygmunt III, naturalıym więc biegiem rzeczy to właśnie tam przybywały poselstwa, które w innej sytuacji docierałyby na dwór królewski: legacje przynoszące prośby wojska kwarcianego ${ }^{3}$ czy postulaty żotnicrzy inflanckich". Dodać do nich jednak trzeba poselstwa związanc z konkretmą sytuacją strategiczną, czyli wynikłe z ożywionych, trudnych i dhugotrwalych kontaktów dyplomatycznych pomiędzy królem a wojskami pozostającymi na shuzbie Dymitra ${ }^{7}$. Druga grupa oracji to mowy ściśle należące do swady wojennej. Wiążą się one bezpośrednio

\footnotetext{
'Mowy wodza do żołnierzy unzggędnili w retorykach np. Michal Radau, Jau Kwiatkicwicz, Nicolaus Caussiinus.

${ }^{+}$Prócz bogatej reprezentacji relacji pamiçtnikarskich są to przede wszystkim rẹkopisy związane z działalnoscią podkanclerzego Feliksa Kryskicgo: rps Bjbliotcku Raczyniskich w Pozmaniu (dalcj: Racz.) sygn. 33 i rps Biblioteki Kónickicj PAN (dalcj: BK) sygn. 324.

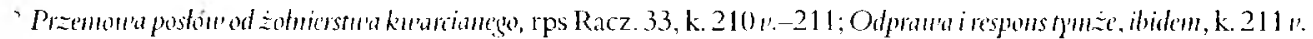
$-213$

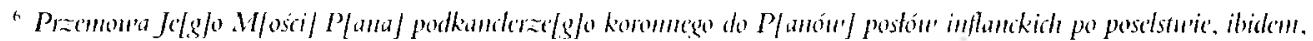
k. $137 \%-138 \%$

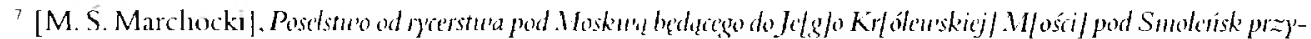

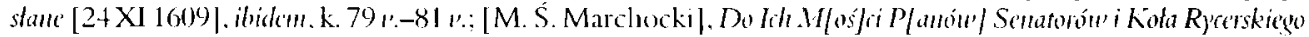

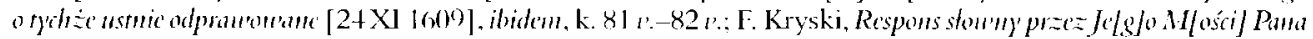

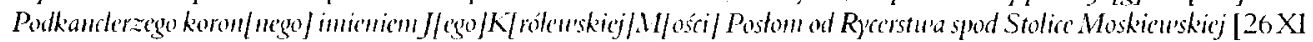

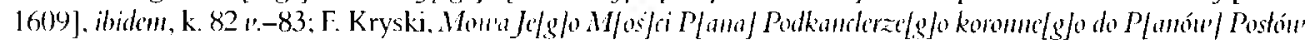

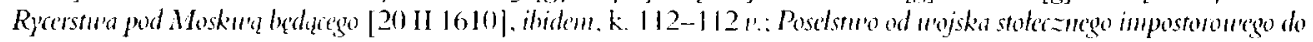


z walką i przynależą do rycerskiego ceremoniału ${ }^{\rtimes}$. Ostatni wreszcie, rysujący się na podstawie oglądı materiałı źródłowego, zespól mów reprezentıje oratorstwo żalobne. W istocie mowy wyglaszane w obozic, np. przy wyprowadzeniu cial znlarlych rycerzy, stanowia jedynie pierwszy akt żałobnego dramatı, który znajdowal swe dopełnienie już na ziemiach Rzeczypospolitej, ale który daje się uchwycić jedynie we fragmentach" "Zresztą mino tak liczıie zachowanych źródel, wszystkie te ocalałe zapisy żywego słowa sąjedynie fragmentem znacznie większej całości. Niejednokrotnie bowiem pamiçtnikarze odnotowują fakt wygłoszenia mowy, której nie udało się odnaleźć, bądź też zachowała się tylko jedna część oratorskiego dwugłosu.

Mowy sąjednym z kilku elementów współtworzących legacje. Oprawą ich byl uroczysty wjazd poselstwa, a następnie samo ceremonialıie traktowane jego odprawianie. Tak na przykład wyglądał wjazd poselstwa 28 stycznia $1610 \mathrm{r}$ :

Posłowie od wojska moskiewskiego, które przy Impostorze pod stolicą [stało], wjechało w obóz JKM. Przyjąl ich honorifice. Potykali [ich] Innci pan starosta białokamieniecki i pan starosta slonimski, więc przed nimi jechało Kozaków zaporoskich choragwi pięć, usarzów nienalo i inszego luda pospolitego z dworzally KJM barzo sita [a sami poskowie bogato ubrani na dobrych jechali bachmatach] ${ }^{10}$.

Odprawianie poselstwa dzieliło się na dwie części: najpierw posłowie wygłaszali mowę, której uzupehnieniem mogła być pisemna legacja, na co odpowiadal w imieniu króla kanclerz, tradycyjnite nazywany „ustami” władcy. Najczęściej był to podkanckerzy Feliks Kryski, alc ponieważ istniał wyraźny podział kompetencji kanclerzy Korony i Wielkiego Księstwa, w przypadku poselstwa moskiewskiego odpowicdzi udzielat kanclerz litewski Lew Sapielua". Taka

KTM pol Smoldrisk 22. Arum sti] 1610. rps BibliotekiZakladu Narodowego im. Ossoliniskich we Wrochawiu (da-

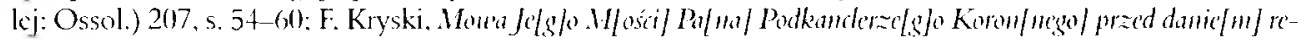

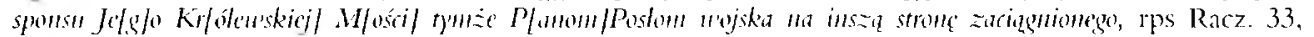

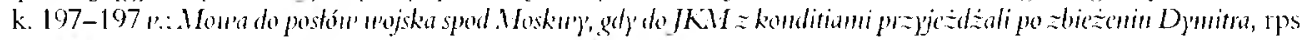
Archiwum Glownegro Akt Dawnych w Warszawic. Archiwum Radziwilowskic II. ks. 10, s. 138.

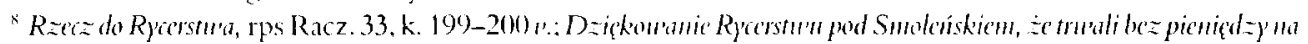

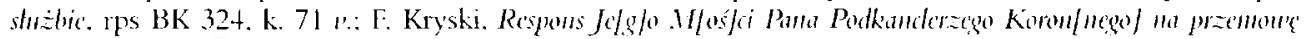

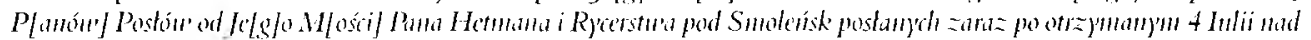

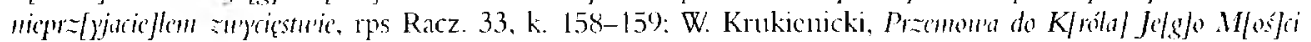

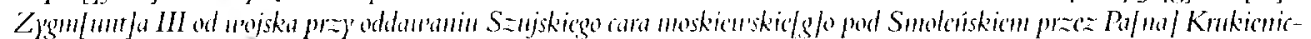
kiegu, rps (Ossol. 647. s. 229-230: [F. Kryski], -tellortatia rycerstu't pod Smoleviskiem do sztumm, rps Racz. 33, k. 201

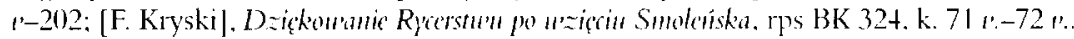

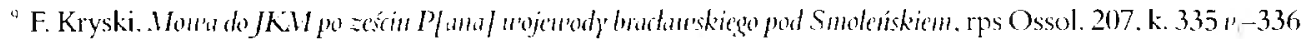

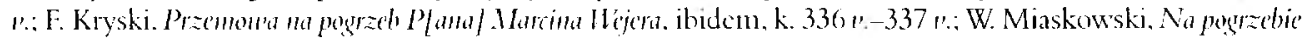

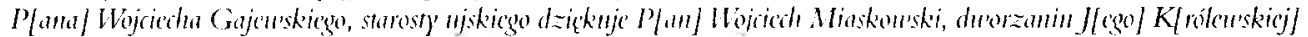

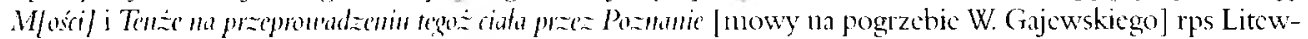
skiego Państwowego Archiwum Historyczncgo (L ictuvos Valstybes Istorijos Archyvas) w Wilnie sygn. 1135. op. $2 / 40$. k. 81 i:-83.

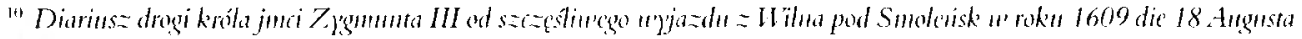

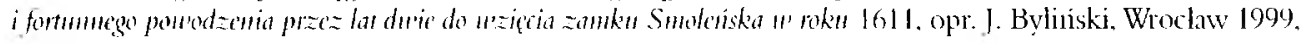
s. 116 .

' Mowy posków moskicwskich znanc z relacji nic są w tym micjscu przedmiotem analizy. 
ustna odpowiedź kończyla się zapowiedzią wzięcial punktów poselstwa na dalszą „deliberacyją", czasem zapowiedzią narady z senatorami. Druga część to uroczysta odprawa poselstwa, w czasie której udzielano ustnej odpowiedzi, po której dopiero odczytywany byl szczegółowy respons przekazywany na piśmie ${ }^{12}$. W tekścic tym nicjednokrotnic powtarzały siç sformulowania z wcześniejszego wystąpienia.

Treść mowy poselskiej i odpowiedzi na nią kształtowaly szczególowe okoliczności: punkty legacji, którym towarzyszyła uzasadniona w danym momencie argumentacja. W przypadku zachowania się i mowy posłów, i responsu na nią ważna jest więc możliwość przéśledzenia sposobów dowodzenia i zbijania argumentów. Jednak w każdej mowie poselshiej oprócz owego zmiennego elementu prośby pojawia się zwykle pochwahne przedstawienie tych, od których poselstwo jest sprawowane, i tego, do kogo się je kieruje. W przypadku mów zachowanych ze smoleńskiego epizodu wojny moskiewskiej strona sprawująca posclstwo zmicnia siç: są to żohnierze z obozu tuszyńskiego, spod Moskwy, przedstawiciele wojsk kwarcianych i inflanckich, ale za każdym razem ich wspólną płaszczyzną odniesienia w prezentacji saınych sicbic pozostaje pojęcic stużby rycerskicj. Z koki adresat przemowy to niemal zawsze król ${ }^{13}$. W mowach poselskich są więc stale przywoływane te dwa wizerunki: polskiego rycerza i wladcy. Uzupełnicnicm oracji posclskicj są tez towarzyszące jej na początku i na końcu elementy względnie stałe, o charakterze niemal formulowym. Szczególnie zdania otwierające legacje, które zawierają pozdrowienie i życzenia, nawiązują do istoty aktu poselstwa, rozumianego podobnie jak list, jako środek kontaktu na odległość pomiędzy tymi, którzy wyprawiaja posła. i adresatem ich poslania. Tak na przykład poselstwo wojska przy Dymitrze ustami Mikołaja Marchockiego pozdrawia króla:

Rycerstwo wszystko, wierni poddani W[aszej] K[rólewskiej] M[ości], którzy się na służbie Dymitra Iwanowicza, cara i wielkiego kniazia moskiewskiego zaciągnęli Waszej K[rólewskiej] M [ości] służby swoje oddają, winszując W[aszej] K[rólewskiej] M[ości] przy dobrym zdrowiu szczçśliwego panowania z pomnożeniem sławy i wszelakiego dobra zacnej Korony Polskiej ${ }^{1+}$.

Epistolarny charakter zachowuje nie tylko formula ofiarowania shuzb $b^{15}$, ale tez bezpośrednie określenia nadawcy i odbiorcy, wyznaczające ramę dla odbioru całego przestania. Poselstwa wieńczą uroczyste wyrazy nadziei na przyszlośc, które słıżą wzmocnieniu postulatów, a jednocześnic, obejmując wspólnotą dobrych skutków i życzeń nadawców oraz odbior-

\footnotetext{
12. Wątpliwości możc budzić status Odprau'y i responsu tymź [poslom wojska kwarciancgo], lączący obydwic formy.

${ }^{13}$ Wyjątkicm jest wygloszonc po mowic do króla posclstwo skicrowanc do luc nnana Stanistawa Źólkicwskic-

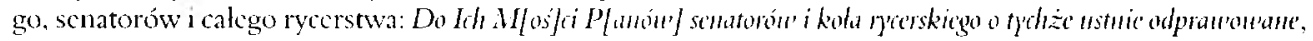
rps Racz. 33, k. 81 1 $1-82$.

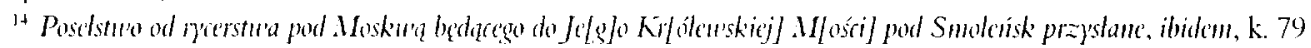
$1:-81$.

1: Wystçpuje ona juz w XVI w. jako formula finalna w polączeniu z gestem ukladania przedmiotu u nóg adresa-

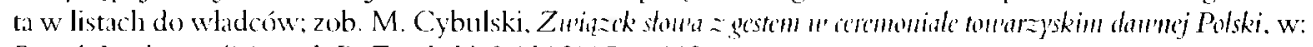
Rytrot. Jezk - religia, red. R. Zarçbski, Lódź 2005. s. 112.
} 
cę, stanowią pozytywny, konieczny w zakoniczeniu emocjonalny akcent. Oczywiście w odpowiedziach na legacje, zgodnie z regulami grzeczności, wyrazom wicrności i zyczeniom towarzyszą zapewnicnia o wdzięcznym ich przyjnowaniu.

Mowy poselskic, których adresatem lub nadawca jest władca, pozostają zawsze pod wpływem regul wyznaczanej jego wysoką pozycją stosowności. Podstawową perspektywą, w jakiej ukazuje się whadcę, jest jego relacja z poddanymi, a oficjalnym jej wyktadnikiem pozostaje związek milości wzajemnej. Łącząc władcę i poddanych, okazywal się on równie poręcznym narzędzieın w prośbach wojsk, odwohujących siç do zasady, że ,jako pan powinncj poddanym miłości przeciwko im pokazać będziesz raczył", jak i w deklaracjach króla. Mógł wtedy z powodzeniem wspierać argumentację odwołująca się do poczucia obowiązku tychże ${ }^{1 f_{1}}$. Drugi, typowy dha pochwały monarchy zespól odniesień to powoływanie się na rolę króla jako pomazańca i na związaną z nią sankcję Boską oraz pobożność monarchy ${ }^{17}$. Z zadaniami króla wiąże się także trzecia, uaktywniona w responsach jego cecha, czyli roztropność: „bo pobożnemu panu obiecować, czego zyść siç nie może, nie godzi" ${ }^{1 \times}$. Pojawiające się w różnych fragmentach oracji odwolania do roli króla najogólniej słuzą ceremonialnemu utwierdzeniu wywyższenia monarchy. Wizerunck władcy okazıje się konstrukcja utworzona ze znanych elementów, które latwo dają się aktualizować i podporządkowywać celom argumentacji.

Równic znajome jak pochwaly króla wydają siç slowa, które odnoszą się do samych zolnierzy. Stale przywolywaną motywacją działania rycerstwa jest stawa. Wznioste powolywanic siç na nią w sytuacjach, gdy przedmiotem poselstwa są jak najbardzicj materialne potrzeby wojska, powoduje, że występuje ona w parze z pojęciem "nagrody” i „chleba" "1". Uzupełnieniem deklarowanego rycerskicgo etosu jest pojęcie słuzbby i męstwa w jej wypehnianiu.

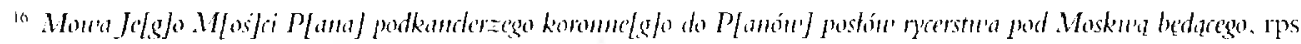
Racz. 33. k. 83: .Cieszy siç / król-dop. M. 13. ]. ze szczçścic to padlo nam. którym siç nickicdy święty dziad IKM chelpil nicraz, ze i slany swej poddancmu w zanadıza, i glowy na lono powicrzyé mógl bezpiecznic. Oto widzi. ż nic tylko w domu. ale i w obcym kraju ta wiara i poddanych jego ku nicmu, toż szczęście i jego ku poddanym siç najduje". Podsmmowujący ten przyktad chiazm: ..ta wiara i poddanych jego kun nicmu, toż szczęścic i jegoku poddanym siç najduje" na pozionnic figuralnym syntetycznic ujunuje ideowe przeslanic. któremu obraz króla-ojca spoczywającego na lonie poddanych-synów zawsze sluzyl. Por. M. Barlowska, Jersy Ossolinski. Orator polskiego baroku. Katowice 2000. s. 112-115.

${ }^{17}$.Co wszystko lasce Jeģo świçtej się przypisuje. Często on narody narodani karze, królestwa krölestuani

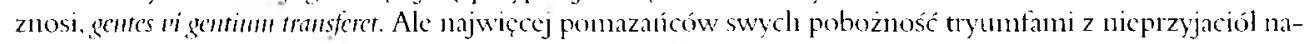
gradza. Onemu samenu gwoli i serca hufcom nicprzyjacielskim odejumuje, i męs wa rycerstwu ich dodaje,

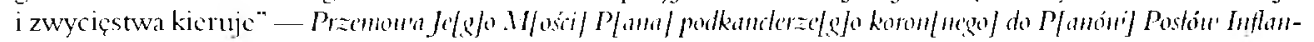
ikidi po posclstulic, ips Racz. 33. k. 138.

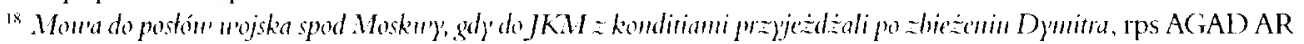
II, ks. 10, s. 138 .

14 Towarzyszy żąanion wobec 7.ygmunta III: .jośli in do tego nic cheac pomagné, przynamnioj im juz nic przeszkadzać, jakoby oni slawy tej i poświçconcj wiary u postronnych narodów na która narodowi swemu z wytoczenicm krwi swojej zarobicli, ni w czym nie naruszając utrat swoich. za skutkicm przedsiçwziçcia swego i nagrodę dostapić noggli" (k. 81) ^.). I usprawiedliwicnionn swoich działan w oczach hetmana i rycerstwa: "Nic nowiun to [...] i przeważnemu narodowi polskicmu, w rozkosznych się wolnościach porodziwszy, w różnych nonarchiach slawy i chleba szablia sobie zdobywá́. i sana wolność by ta zawsze pobudką do wszelakicj przewagri w rozmaitycl nacjach, i to by to za jakieśs sommarimm, skąd wiele lud zi rycerskich w zacnych posługach dzichnością swą (ojczyźnic stużcli” (k. 81 r.). 
Najkrócej obowiązek rycerza zanyka się w zobowiązaniu wypowiedzianym przez poslów wojska kwarcianego: „by się też [ . . | wojsko nieprzyjacielskie nam ukazało, nie ogląda grzbietów naszych...".

Jednak mowa od wojska kwarcianego jest też przykladem zupehnie innego perswazyjnego wykorzystania rycerskiego etosu. Całą niemal wypowiedź posłów wojskowych wypehnia proste i utrzymane w niskim stylu opowiadanie. Rycerze ukrainni zalą się:

w obozie będạc, bylichmy ściśnicni niedostatkiem żywności i niewdzięcznością ludzką przez niedziel piętnaście, żechmy z obozu aż do ziemi woloskiej posylać musicli z pieniçdzmi na targi, dostawając [...] chleba [k. 210 k'.]:

potem, po późnojesiennym pościgı za Tatarami

pozdychało nam koni niemało, tak iż niektóre towarzystwo pieszo do włości, szkapy niepozdychale, chude i poranione przed sobąśmy pędzili [k. 211],

a dalej „w ciągnieniu” (czyli podczas marszu) „bochna chleba, kurkiej biednej dać nie chciano”, a jeśli ktoś wziąt „,bydlę jakie albo owsa miarkę”, pozywano przed trybunaly i „potrawilichmy się, prokuratorom ręce smarując”, "konie pocztowe za półcenek przedawać musieliśmy". Ta utrzymana w tonacji lamentu opowiéść o żołnierskicj niedoli służy oczywistej perswazji emocjonalnej, która ma pomóc przekonać króla, by wyplacil wojsku coś więcej niż otrzymane dotąd dwie ćwierci. Jednak perswazyjną skuteczność tego zabiegu pozwala ocenić dopiero skonfrontowanic go z odpowiedzią wladcy. W niej również pojawily się odniesienia do rycerskiego etosu:

Sprawy wojenne i czyn ryccrski jako jedno na świccic nastał, nigdy nie byl taki, aby wczasy, deliciac i bogactwa przynosil. Kto się kiedy nieprzyjacielowi, a zwłaszcza rączemu pogaństwu, z którym dzielo swe to tam wojsko mialo, stawić w oko niezmyślenie clicial, kto go i fortelnych ubiegów jego dojść sobie życzyl, ochotno, pracowito, rączo postępować musial, nic tylko końskim, ale i wlasnym swym nie wygadzając wczasom. A cokolwiek w tym wszystek ucierpial żolnierz: niedostatku, głodu, ucisku - sławie swej gwoli, nie skarżąc się, odnosil. Bo co miękkie materace delikatom, co lekkie letniki wczaśnikom, co perfumowane purpury rozkosznikom, to wojlok, siodło, zbroja żołnierzowi mężnemu być musi [k. 212].

Polemika dokonala się tu poprzez przeciwstawienie językowi lamentu innego obszaru dyskursu o sprawach rycerskich. Z ctosem rycerskim przecież od zawsze wiązaly się surowość i prostota życia przeciwstawiane światowym rozkoszom. Niską codzienność wojny powinna wiçc pokonać wzniosła, duchowa motywacja. Tam, gdzie jej brak, jako odpowiedź pozostaje nie język wspólczucia, ale satyry. Jej ostrze, choć skryte w uogólnieniu, zwraca się w stronę mocodawców poselstwa. Logika okizıje się tu dla nich druzgocąca: bo skoro tylko 
ten, kto się nie skarży i radośnie przyjmuje trudy, jest mężnym rycerzem, to ci, którzy się skarżą, na miano takie nie zasługuja. Odpowicdź uderza więc w podstawę ich argumentacji.

Ogólnie przyjęte, niedyskutowalne dla spoleczności twierdzenia i wielokrotnie wywodzone z nich argumenty stanowią nia pewno ceremonialną nadbudowç poselskich przemów, są splatą daniny na rzecz. języka oficjalnego, wymaganego hicrarchią osób i okoliczności. Ale jednocześnie wspóltworzą perswazyjny i politycznie znaczący wymiar przemów.

Pośród mów poselskich niewątpliwie największą sławę zyskala legacja sprawowana w imieniu wojska tuszyńskiego w początkowym etapie oblężnia Smoleńska 24 listopada 1609 roku. Mikolaj Scibor Marchocki zapisal:

Odprawilisiny poselstwo do króla Junci i do rycerstwa z osobna, przy czym byl i sam hetman Zólkiewski, byli i pulkownicy i rotmistrze. Jam obie odprawowat ${ }^{21}$.

O zaninteresowaniu, jakic wywolata i treść, i forma owegro posclstwa, świadezy uwaga Stani-

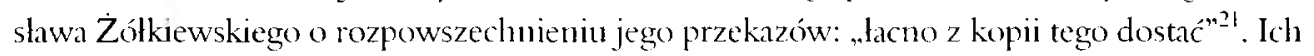
krążenic musiało rozpoczą́ siç już w obozic, bo odpowiadajac posłom (26 listopada), Feliks Kryski powolywal się na zdziwienie tych, „co lubo czytali, hubo shuchali poselstwa tego”. Natomiast poselstwo do he tmana i wojska wraz z odpowiedzią na nie udzieloną ukazało się jako anonimowy druk, element akcji propagandowej towarzyszącej wyprawic moskiewskiej ${ }^{23}$.

Stowa kierowane przez postów wojskowych do króla, zgodnie z przewidywaniami kanclerza Sapiehy, okazaly się zuchwate ${ }^{23}$. Zasadę organizującą ich wystapienie nazwal trafinie w odpowiedzi od króla Kryski, formułując wątpliwość, czy się .rzecz z słowy stosowala". Znalazły siç bowiem w poselstwie sformulowania, które w pelni odpowiadaly wymogrom oficjalıego języka. Przede wszystkim rycerstwo ustami swych poslów ofiarowalo królowi swoje słuzby, dalej poslowic przedstawili pokorna nuntywacje swych działani:

\footnotetext{
pocz.uwając się w powinncj miłości, którą powinni Ojczyźnie swojej i W[aszej] K[rólewskiej] M[ości], Panu swemu Milościwemu, obawiając się, żeby za tym wyściem ich z Korony w obce kraje na słuzbę Dymitra Iwanowicza W[asza] K[rólewwska] M[ość] i Rzz[ecz]plospo|lita rebelless i swawolnych ich rozamieć nie raczeli...;
}

\footnotetext{
"M. S. Marchocki. Historia "oyny moskicuskicj. Poznan 18+1, s. 59.

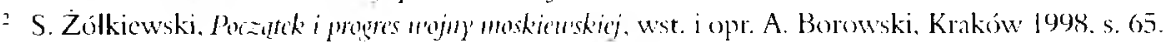

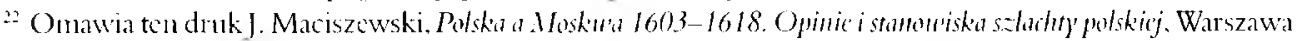

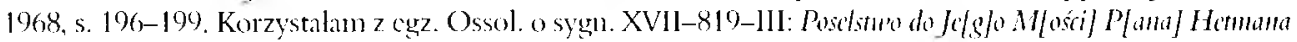

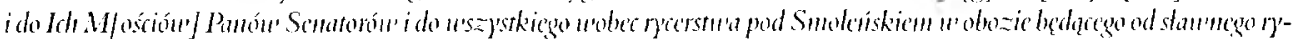

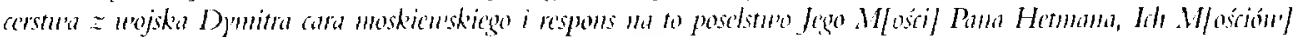

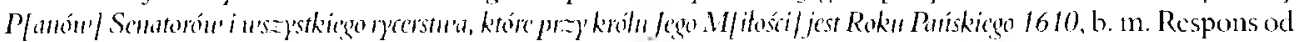
lictmana, scnatorow i rycerstwa un poselstwo z 24 XI $60(19$ r. to prawdopodobuic forma pisana. jak wskazuje

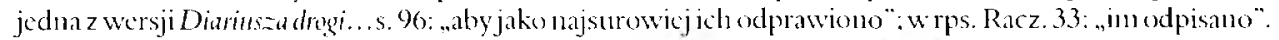

2.- Jutro mają posclstwo sprawować (i bẹdą móxić) jako baczẹ. dosyć zufale: ze król na zasługi ich następuje, że in przeszkadzi, owa znać w nich rokoszowe duchy": cyt za: W. Sobieski, Zólkionski mo Kremh. Warszawa [1925]. s. 6t.
} 
wyrażali nadzicje związane z postçpowaniem króla, dotąd

patrząc na takie życzliwe chęci ich przeciwko W[aszej] K[rólewskiej] M[ości] i Ojczyźnie, im tym więcej do tego milościwą radą swą (co oni za osobliwą pobudkę do sławy i cnoty rozumieli) mialeś być pomocen...,

i jeszcze bardziej poruszająco w przyszłości:

W[asza] K[rólewska] M[ość] jako pan powinncj poddanym swym miłości przeciwko im pokazać będziesz raczył. Rz[ecz]p[ospo]lita jako matka, miasto chleba, którego się krwawie dobijają, kamieniem karmić ich nie będzie chciala... -

wreszcie blagając:

Tą nadzieją się szczycą w tak wielkich pracach i wczasach swoich, iz W[asza] $\mathrm{K}$ [rólcwska] M|ość] laskawie dobrymi oczyma wejrzeć będziesz raczyl na tak wiele przelanej krwie braci ich, na tak wiele juz mogilani pokrytych wiecznc palace mają, tak wiele na czlonkach zeszlych zostało, tak wicle z majętności i z dostatków ich zhupionych, co wszystko dla slawy Ojczyzny, a potym prawie [z] krwią zamieszanego chleba podjęli...|k. 81].

Tej narastającej emocjonalności próśb odwolujących się do calego sztafażu przyjętych i stosownych środków przekonywania króla towarzyszy jak kontrapunkt również wznosząca się linia oskarżeń. Zaczyna się od jednego „ale”, w którym kryje się zarzut nieslowności („Ale to zaś weście W[aszej] K[rólewskiej] M[ości] w ziemie cara J[ego] M[ósi] nie korespondıje tantemu responsowi”), po nim pojawia się motywowany strategicznie zarzut dzialania na ich szkodç:

przekladając przez nas W[aszej] K[rólewskiej] M[ósci] trudy, krwie przelania i koszty swoje, które za nastąpieniem WKM z wiclką urazą i szkodą swą muszą odnieść, gdyz $|w|$ przedsięwzięciach swoich do umyślonego skutku trudno by przyjść mogli przez oderwanie się od cara J[ego] M[oś]ci obywatelów moskiewskich... [k. 80 (.).

Następnie „rycerstwo żąda i prosi”, w czym już pobrzmicwa pogróżka,

abyś W[asza] K[rólewska] M[ość] na tych poddanych swych jakowych szkód nie wewlóczyl, które by in do niewycierpienia ich okazyją dać musialy.

Wreszcie wypowiedziana zostaje jawna groźba, której pozonnie odbiera znaczenie subnexio:

Oświadczają się W[aszej] K[rólewskiej]] M[ości] przez nas, iz jako niggdyhostiliter nie myśleli Ojczyźnic, tak i teraz jako dobrzy synowie wszystkiego dobrego jej życza, z taj jednak deklaracją, gdzic by kto za czyimkolwiek między nas dolo malo perswazjanni na państwa cara J[ęgo] M[óści] i na zdrowie jego następując, 
namn przeszkodą był w zasłıgach, czego oni o W [aszej] K[rólewskiej] M[ości] panu swym i o braci swej nie trzynają. gdyż by in to już nie Ojczyzna ani pan, ani brat czynil, jedno by siç inn w tym gwalt już dzial $[\mathrm{k} .80(1,-81]$.

Slów tych przecież nie lagodzą następujące po nich zdania o kochającym królı i Ojczyźnie matce, pojawia siç raczej dziwny, emocjonalny kontrast. Ulega on jeszcze wzmocnieniu w końcowym zestawieniu zdań, z których niedwuznacznie wynika, że król polski jest „nieprzyjacielem" "2t obok pokornego blagania o wzgląd na krwawe ofiary. Jest to zestawienie tak odległe, że powodıje dysonans poznawczy, stawiając odbiorcę wobec konieczności wyboru. Trudno bowiem zaakceptować prawdziwość obydwu linii dowodzenia. Miat rację więc podkanclerzy, zarzucając postom nieprzystawalność słów i rzeczy. Trzeba by tylko rozciągnąć pojęcie „słów” na wszystkie opisane konwencją sposoby mówienia wobec władcy, a jako „rzecz” potraktować kryjącą siç pod nimi rzeczywistość i grę politycznych interesów.

Poselstwo tuszynian zostalo podobno przylęte "niechętnie i z sarkaniem”- Ale rozpoczynając mowę przy odprawie, podkanclerzy przypomniat:

Wdzięcznic siç onegda to powierzchne oświadczenie wiary i poddaństwa tego tam rycerstwa przez W[asz] m[oś]ciów przyniesione od Je[g]o K/rólewskiej] M[ośc]i przyjęło.

Być może więc rany konwencji okazały się na moment silniejsze niż oczywistość rzeczy. Sam jednak respons wyraźnie wskazıje, ze słowa poslów oceniono ostro:

Z niesmakiem i urazą nie tylko majestatu, ale i zwykłej dobroci swej pańskiej J[ego] K[rólewska] M[ość], Pan nasz M[iłościwy] takiego poselstwa [...] slıchat...

Z tą deklaracja współgra forma odpowiedzi. Podkanclerzy przemówil krótko, użył zdaí prostych i zdecydowanych. Prócz bezpośrednicj nagany znalazl siç w mowie tylko jeden fràgment o charakterze refutacji:

Czemu tak zuchwała i ostra rzecz z łagodnymi stowy pomieszana? Czemu poddaństwo i ta ofiarowana wiara ważyła siç na pana swego tak bezpiecznie rzucić? Już to z wolności wyszlo. Na Ojczyznę się ten rzuci, kto pana nie szauuje, na prawo się miece, kto zwierzchność znicważa. A kto Ojczyznę i prawo jej gwałci, wychodzi z brzegów wolności, aniby siç ją szczycić w wystçpku już mógł więcej [k. $\left.82{ }^{\prime}.\right]$.

\footnotetext{
2- „In też nic życząc aby oni tantenun nieprzyjaciclowi. króry juz prawie zwąelony. odżywić siç nusicli dac. a na tego pilnc oko nuić, który by im dobrze nadrobioncj. tylko juz nicskończoncj roboty. prawic krwawym źrúdlem zatopioncj roboty przeszkadzać clucial".

25 Diarius drogri..., s. 96 .

${ }^{26}$ F. Kryski, Respons stomin'.... k. 82 $t$.
} 
Pytania podkreślają oczywistość zuchwałego postępowania posłów. Subiectio przedstawia ostateczne jego wyjaśnienie. Kolejne zdania są blyskotliwie przeprowadzonym dowodem prawdziwości udzicloncj odpowiedzi. W formę sentencji zamknięte zostało podwójne wynikanie. Jego wspólny element - nieposzanowania pana, czyli zwierzchności, zostal ukryty przez zastosowanie antytetonu i synonimii. Rozpoczyna on konstrukcje szeregowa dowodu: kto nie szanıje pana-zwierzchności, ten gwałci Ojczyznę i prawo, a kto tak czyni, przekracza ramy wolności. W ten sposób ocena działań posłów stala się podstawą dowodzenia, którego precyzyjna forma narzucała jej oczywistość. Ostateczny wniosek natomiast odbieral inn nié tylko rację, ale prawo do zabierania głosu w ogóle. Poselstwo tuszynian okazato się więc jedynym przykładem przekroczenia nonn sprawowania poselstw intra reg"um!, z dumą traktowanych jako wyraz polskiej wolności ${ }^{27}$.

Wygłoszone w obozie pod Smoleńskiem oracje, reprezentujące swadę wojenną w ścisłym znaczeniu, są częścią wojennego ceremoniału. Obejmuje on przed bitwą napominanie rycerstwa, czyli bojową pobudkę, która jest obok praktyk religijnych, ważnym elementem duchowego przygotowania do walki, po bitwie natomiast - uroczyste oddawanie znaków zwycięstwa i jeńców oraz podziękowanie rycerstwu. Wszystkim tym oracjom towarzyszy odpowicdnio przygotowana scena, obejmująca przede wszystkim jako wspólbohaterów i jednocześnie odbiorców zbiorowość żolnierską. To na ich tle pojawiają się w odpowiednio uroczystej oprawic mówcy, którzy swoimi wystapieniami komentują i niejako uwznioślają wydarzenia.

Pierwsza uroczystość świętowania zwycięstwa odbyła się w królewskim obozic po zwycięstwie kluszyńskim. Posłowie od hetmana przybyli 15 lipca, a 18 odbyło się przyjęcie ich legacji:

Oddali znak zwycięstwa: bulawę Szujskiego i kilkanaście chorągwi, między którymi samego Szujskiego beła, i te, które przy JM panu hetmanic zostały, opowiedzieli ${ }^{2 s}$.

Bulawę oddawal bratanek hetmana, Adanı Źólkiewski ${ }^{20}$. uczestnikiem poselstwa byl też Mikotaj Marchocki". Treść legacji została utrwalona w Diarinszu drogi króla Jmci Z lymunua III..., w calości natomiast zachowal się Respons Je[g]o M ośfci Pana Podkanderzego koronlnego] na przemou'é P[anón'] postón od Je[g]o M ości] Pana hetmana i neerstu'a pod Smolenisk postanych zaraz

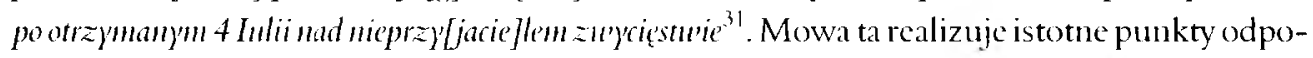
wiedzi na poselstwo. Podkanclerzy Kryski w imieniu króla wdzięcznie przyjınıje zwycięstwo

\footnotetext{
${ }^{2}$ M. Radau, Orator extemporanews..., Anustelodami, apend I. a Meurs, 1655. s. 470.

^Diarius drogi.... s. 165 .

$\because$ W. Sobieski, op. cit., s. 111.

"M. S. Marchocki. op cit., s. 93: „stąd zaraz postani byli posłowic do wojska pod Smoleńsk: pan Zborowski i pan Struś, i nicktórzy insi. Bylem i ja do króla Inci. oddajac nu zuaki zwycięstwa bitwy kluszyńskiej, więc i to, żc owi, co byli w gródku. ośn tysiçcy wojska moskiewskiego na imiç królewicza Jmci chrest calowali”.

"Rps Racz. 33. k. 158-159: przedrukowany ostatnio przez Martç M. Kacprzak: Spraura Smolenisku. Z literutwry

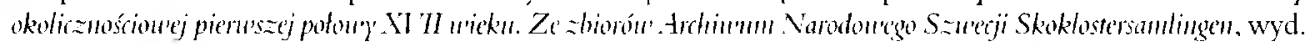
M. M. Kacprzak, Warszawa 200o (Polonika w Zbiorach Archiwum Narodowego Szwecji t. 2), s. 39-40).
} 
i jego dowody 32 . Obiecuje nagrodę za poniesione trudy i daje nadzieję na przychylne rozpatrzenic, po naradzie z senatorami, postulatów rycerstwa. Jednak podstawowym celem oratora jest pochwala rycerskiego czynu. W egzordium jest to laudacja czyıu rycerskiego w ogóle, która następnie zostaje odniesiona do postawy żohnierzy spod Kłuszyna, i dalej to oni i ich dowódca stają się przedmiotem bezpośredniego wywyższenia. Już na początku sięgnął mówca po znany z epiki heroicznej topos „czynów trzeba, nie slów."3.3.

Jeśli które dzielo na świecie, jako rycerskie rzeczy samej potrzebuje. Bo w nim i subtelne przemysły, i wymyślne fortele, i naodważniejsze serce, dokąd rzecz nie przystąpi - nic nie sprawi; ręki tu trzeba, która sprawy tej serce i silę rzeczą samą oświadcza. [...] A rzecz, która nie słów potrzebuje, bo sama od sicbie mówi, spraw swych i ręku w[asz]m[oś]ciów godna, a sławie Je[g]o K[rólewskiej] M[ości] i narodów naszych przystojna ${ }^{3+}$.

Tonację heroiczną podkreśla równiez wprowadzenie sentencji z Plutarcha ${ }^{35}$ i jej parafraza shużąca amplifikacji:

By on był teraz, co exercitum cenronmm duce leone kiedyś chwalił, widział tę rąk waszych robotę, ujrzałby byl, jako dowodzi exercitus leonmm duce leone, ujźralby byl, jako nierówno smarownicj rzecz idzie, gdy lew, gniazdo swe prowadząc, ów rozumem i sercem prowadzi, a ci - męstwem i dziełem dowodzą [k. $158 \%$.]

Każdy z rycerzy przez symbolikę lwa zostạje więc zrównany z. męstwem Achillesa. I la wyolbrzyınienia chwaly zwycięstwa Kryski wykorzystıje zresztą caly zestaw pochwalnych toposów: przeciwstawia wiclość jedności („tak wicle cudzych nacyj $\mid .$. | w jednę godzinç zwyciężyć”), powołuje się na świadectwa narodów, wprowadza definicje doskonałej śmiałości, cnoty i miłości (nadając im silne nacechowanic emocjonalne przez interrogatio). Najogólniej spetnia wszelkie wymogi w zakresie inwencji i elokucji mowy przynależnej do generis demonstrativi, shużącej utwierdzeniu wspólnych wartości i dostarczającej słuchaczom przeżyć estetycznych.

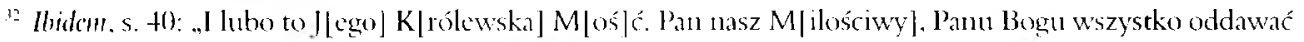
i przypisować raczy, lubo sprawiedliwości swej przed troncun Je [go] świçtym zawszc ufal, sprawç jednak i sta-

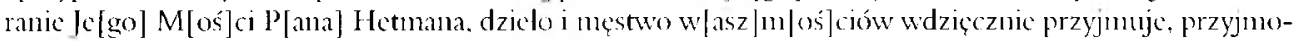

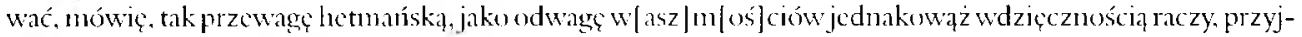

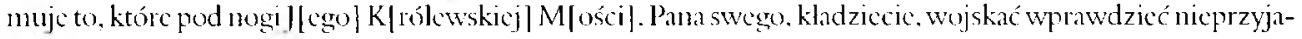
ciclskicgo skory. ale świcze mçstwa w|asz|m|ośfciów świadectwo...".

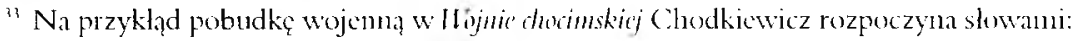

Polc, mówiç. nie słowa, nic czczcj pary dźwiç̣ki.

Alc kocha roboty bohatyrskicj ręki.

${ }^{3}$ Rps Racz. 33, . 158.

${ }^{35}$ Por. objaśnicnia w: Spran'a Smodvisk'a .... op. cit., s. 115 
Oracja przy oddawanıu znaków zwycięstwa znana byla oratorstwı sejmowemu. To zwykle na scjmowym theatmim po oddawaniu zdobycznych nieprzyjacielskich choragwi odbywało siç dziękowanie hetmanon i rycerstwu w imicniu króla i stanów Rzeczypospolitej jo. Do takich tryumfów nawiązywata teź najstynnicjsza chyba, wiclekroć opisywana i niezwykle widowiskowa uroczystość: oddawanie przez Stanisława Zółkiewskiego carów Szujskich podczas sejmu 29 października 1611 roku $^{37}$. W relacji Samuela Twardowskiego we W7adystaw'ie IV pojawia się charakterystyczne pytanie retoryczne:

Rzecz li beła podobnakiedy być widzianej

Scenie u nas takowej, że, który tyrany

Przeszedl wszystkie daleko ostatniej północy,

Stat jako otarczony i nie o swej mocy

Przed majestatem?

Być może nawiązat tı epik do znanej nowy Feliksa Kryskiego, którą odpowiadat on i dziękowat he tmanowi, rozpoczynającej się od słów: „Ceremonia ta, miłościwy panic hetmanic, jeśli kicdy w Polsce na tym placu bywala...". Gdyby nawet tak bylo, to nie byloby to pierwsze takie skojarzenie i picrwsze oddawanic carów Szujskich. Wcześniej ceremonia oddawania przekazanych Żółkiewskiemu Szujskich miala bowiem miejsce w obozie pod Smoleńskiem po powrocic letmana z Moskwy (po 9 listopada 1610 roku) ${ }^{34}$. Z prawdopodobnie kilku towarzyszących uroczystościom oracji zachowala się Praemou'a do K[róla] Je[g]o M/ości Zygmunta III od wojska przy oddan'aniu Szujskiego pod Sundenskiem praez Pa[na] Krnkienickiego". I w tym wypadku w ramy mowy poselskiej zostala wpisana przede wszysthim pochwała rycerstwa. Posel wojskowy przez nagromadzenie argumentów konsekwentnic dowodzil tegoż rycerstwa „stateczności” i „ochoty do shuzb pańskich”, a więc jednocześnie gloryfikowal sa-

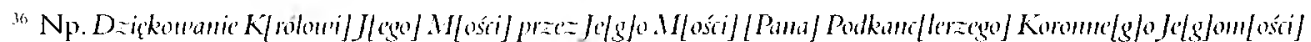

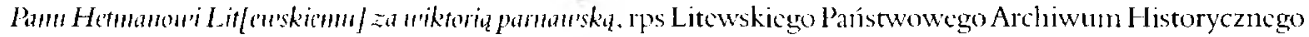
1135 , op. 2/40. k. $2(17-2017$.

${ }^{27}$ Zob. J. Bylinski, Sejm z wok" 1611, Wroctaw 1970. s. 153-157.

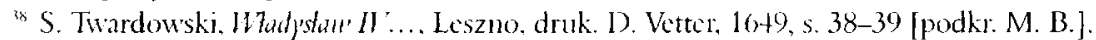

"W Dianiuszudregi.... s. 193. odnotowano 9 listopada 1610: .JM pan letman koronny do obozu KIM wjachal, przeciwko niemu JM panowie senatorowic naszy wszyscy, dworzan sila KJM wojska część wiçtsza wyjechała. Wita JM pan kanclerz litewski inicniem wszytkich i honoricentissime go do stanowiska doprowadzili. Wespól Wasila Szujskiego, który by carem. przyprowadzomo". I letman wital króla następuego dnia. 11 listopada poselstwo od wojska sapiezyńskiego mial Stefan Kazminicrski. natomiast 13 listopada ..Poselstwa od rycerstwa z stolice przed KJM odprawowaly się”. 26 listopada wiçźniów odestano do Molnilowa: „on [Źólkicwski -

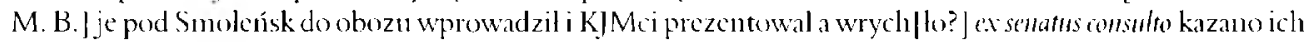
na zatrzymanic odestać do Polski".

11) Rps Ossol. 647. k. 13-14. O samym mówcy nicwick wiadomo. A. Boniccki podaje tylko, ze Wincenty Krukicnicki podpisal z województwem ruskinn clekeję Whadyshawa IV. Z zachowanych w rękopisach nów Krukicnickicgo wynika. ze by on postacią w wojskn ceniona. kilkakrotnic howicm sprawowal posclstwa do króla, np. po spalcniu aktu konfederacji wojskowcj. na ckckeji Wladyslawa IV wypowiadal siç przeciw rozdawaniu godności mlodym przedstawicielom moznych rodów z pominiçciem zasłuzonych żolnicrzy. powiedzial wtedy o sobie: „Od młodości mojej aż do tego siwego wdosa samego Rz[eczy]p[ospo]l i] tej Ojczyźnie swojej w wojskıı słıżąc..." [k. 11]. 
mego wadcę. Znalazlo się wśród nich wspomnienic o walkach z postronnymi nieprzyjaciótmi, ale i przywolanie wydarzeń rokoszowych ${ }^{4 !}$. Wieńczy jednak to nagromadzenie, szczególnie staramie opracowanc przez użycie anafor, paronomazji i wyrównanie członów, przedstawienie wyprawy moskiewskicj:

Swiadkiem jest stateczności naszej statecznce w ustawicznych pracach dotrwanie, świadkiem powolności skromne w niedostatku upominanie placej, świadkiem ochoty wielkie nasze utraty podjęte na shużbie W[aszej] K[rólewskiej] M[ości], świadkiem i krew braciej naszej wylana na oświadczenie tej ochoty naszej. Swiadkiem J[ego] M[ość] P[an] I Ietman, wódz nasz, któremu jeśli kiedy co na tej ochocie zeszlo, niechaj da W[aszej] K[rólewskiej] M[ości] sprawę. Swiadkiem na koniec tak zacne insignia slawnego zwycięstwa, które P[an] Bóg dał za szczęściem W[aszej] K[rólewskicj] M[ósi] przez odwagę J/ego] M[ości] P[ana] I Ietmania a dzielność tego cnego rycerstwa pod nogi majestatu W[aszej] K[rólewskiej] M[ó́ci], P[ana] N[aszego] M[iłościwego]. Który kiedy hetman i które rycerstwo kladli pod nogi królom polskim, panom swoim tak zacne hupy zwycięstwa swego? Oddana albowiem jest armata, oddane choragwie, oddany hetman, oddany gubemator wszystkiej ziemie, oddany na koniec pan ze wszystkim państwem swoim. Zaprawdę pierworodne zwycięstwo dał P|an] Bóg narodowi naszenu za szczęśliwym panowaniem W[aszej] K[rólewskicj] M[ości], P[ana] N[aszego] M[milościwego [k. 13 ".].

Anafora „świadkiem jest” nadaje amplifikacji szczególnie uroczysty charakter. Zaciera ona bowiem przez swa powtarzalność granice miçdzy użyciem slowa literalnym, argumentem ze świadectwa (tutaj autorytet hetmana) i figuralnym. Figura myśli opisywana przez Sarbiewskiego jako interpretacja

ma na celu uczynienie czegoś bardziej wyraźnym przez to, że prawda znajduje pewne potwierdzenie w świadectwach rzeczy niemych ${ }^{+2}$.

Krew, insyggnia zwycięstwa, świadczące na chwałę rycerstwa, przez swą niezwykłość jeszcze lepiej sluża amplifikacji. Natomiast podsumowıjące pytanie retoryczne, przez zaprzeczenie, by kiedykolwiek wydarzylo się coś podobnego, stosuje ten sam schemat wyniesienia niezwykłości zwycięstwa, który będzie towarzyszył spektaklowi oddawania Szıjskich na scenie sejmowej.

Zakończenie mowy to powrót do istoty poselstwa: „oddawszy to, co dobrzy shudzy panı powinni”, rycerze przymawiają się o królewską laskę i nagrodę. Stała obecność motywu na-

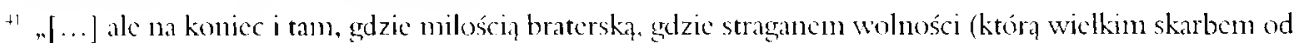
przodków naszych zostawiona jest nam) od służb W/aszej| K[rólcwskicj] M[ości], P[ana] N[aszego] M[ilościwego oderwać nas claciano, oświadezyliśmy krwią swoją stateczność naszę, stanąwszy za powodem J[ego] $\mathrm{M}$ [ości] l'ana | Hetmana, wodza swego przy dostojeństwie W|aszej| K/rólewskicj| M|ości]. P [ana] N[aszegof M[ilościwego]" |k. 13 r.|.

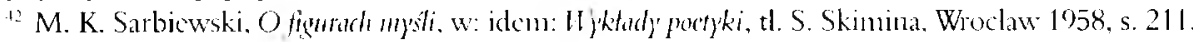


grody w oficjalnych wypowiedziach wojskowych legatów to nie tylko element formuly odwolującej siç do roli taskawego króla - w Rzeczypospolitej rozdawcy chleba dla dobrze zasłużonych — ale też jeden ze śladów wagi spraw pieniężnych, narastania problemów placy dla wojska. Znajdowaly one wyraz w relacjonowanych przez pamiętnikarzy zaburzeniach w obozie królewskim (np. 20 sierpnia 1610) roku wojsko odmówiło pójścia do szturmu), ale też w języku oficjalnych dialogów władcy w poddanymi. Śladem tej znacznie mniej widowiskowej, ale jakże ważnej swady wojennej są dwie mowy: Rzecz do rycerstu'a ${ }^{43}$ i Dzię́kon'anie rycerstu'u pod Smoleniskiem, że tru'ali bez pieniędzy $y^{+4}$. Obydwa wystapienia to wypowiedzi w inieniu króla, prawdopodobnic Feliksa Kryskiego. W pierwszej mowie wyjaśnieniom dotyczącym opóźnienia wyplaty żoldu i podziękowaniom za „potrzebną dyskretią” towarzyszy odrzucenie prośby wojsk o porównanie ich z uczestnikami zwycięstwa kluszyńskiego i wyplacenie dodatkowej ćwierci. W polemicznym fragmencie wystąpienia orator uciekł się nawet do erystycznego zastosowania retorsio argumenti. Odrzuceniu prośby towarzyszy bowiem następujące, niezbyt pochlebne dla wojsk pod Smolcrískicm, uzasadnienie:

A słusznie, bo kto z kim nie rad by partycypowal, uchowaj Boże, w nieslawic, kto by z kim nie chciał komuniować w szkodzie i w nieszczęściu, po co napierać się tego ma, co on za przewagą swą, za niebezpieczeństwem swoim z laski pański bierze $[$ k. $200-200 \%]$.

Jak wskazıje treść i miejsce oracji w kopiariuszu, została ona wygłoszona pomiçdzy 14 września a 24 października 1610 roku. Natomiast krótkie dziękowanie za trwanie na służbic, w którym mowa o długich ,traktatach i targach" z nieprzyjacielem, nędzy i niedostatkach polskich wojsk, można by sytuować na przełomie listopada i grudnia 1610 roku ${ }^{+5}$. Targom z wojskiem towarzyszyly zresztą nie tylko królewskie podziçkowania. 7 lipca 1610 roku

JM pan podkanclerzy koronny imieniem KJM in frequentia rycerstwa przy KJM mowę mial do żohnierzów, prosząc i napominając. aby stateczni na posłudze JKM byli ${ }^{+6}$.

Bezpośrednio z atakami na Smoleńsk wiązą się dwie mowy: opublikowana niedawno przez Martę Kacprzak Adhortacyja neerstu'a pod Smolénskiem do sztumm i Dziękouranie rycerstu'u po uziçcin Smolenska. Obydwie zostały wypowiedziane w imieniu Zygmunta III. O przypisaniu dziękowania Kryskiemu decyduje świadectwo Stanislawa Kobierzyckiego, który, opisując uroczystości towarzyszące zdobyciu Smoleńska, przekazal treść mowy kasztelana kamienieckicgo Jakuba Potockicgo winszującej królowi zwycięstwa, i informację, żc odpowiedzial imieniem króla podkanclerzy. Porównanie treści Dziękou'ania... ze streszczeniem gratulacji

43 Rps Racz. 33, k. 199-200\%.

"Rps BK 324. k. 71: Ossol. 207, k. 451 - 46.

15 Wojsko nic chcialo wtedy podjać szturmu aż do porównania w zaplacic z wojskicm. które pozostawalo w. Moskwic - por Diariusz dragi.... s. 198.

I6 Ibidem. s. 157. 
jednoznacznie wskazuje, że jest ono wlaśnie oracją towarzyszącą zdobyciu miasta, wygloszoną 14 czerwca 1611 roku. Natomiast umieszccenie adhortacji w kopiariuszu zawierającyı niemal wylącznie mowy Kryskiego czyni i w tym wypadku jego autorstwo wielce prawdopodobnym. Trzeba się zgodzić z edytorką naponinaınia do szturmu, że tréść mowy niè wskazuje konkretnego jego momentu, jednak umieszczenie zapisu napominania w konsekwentnic chronologicznie uporząkowanym zbiorze dokumentów moskiewskich pozwalakby związać przemowç raczej z jesicnią 1610 roku.

Adhortacya rycerstu'a do szturmu... to wyjątkowo zachowany dokument funkcjonującej wXVII w. nie tylko na kartach poematów i kronik bojowej pobudki. I znów nie jest to na pewno ślad jedynej ekshorty, jaka wygłoszona zostala podczas wyprawy. I sam Zúlkiewski, i Samuel Maskiewicz pozostawili w swych relacjach świadectwo, że walkę pod Kłuszynem poprzedziła wygłoszona przez wodza mowa zagrzewająca rycerzy ${ }^{+7}$. Smoleńska adhortacja niewątpliwie nawiązuje do opisanego przez retorów i szeroko praktykowanego zarówno w literaturze, jak historiografii juz od czasów starożytnych, wzorca pobudki ${ }^{\text {th }}$. Znalazło siç w nicj przede wszystkim ukazanie sprawiedliwych przyczyn wojny, leżącyclı w zdradzieckim zagarnięciu Smoleńska, w złamaniu przez Szujskiego przymierza, wreszcie w dotyczącej wszystkich pomście za „krew braci naszej”. Są to motywy znane z pism ulotnych wspierających politykę królewską ") choé w tym momencie raczej wspóltworzące perswazję emocjonalną, charakterystyczną dla ekshortacji. Szczególnie ostatni argument, jak zauważyla Marta Kacprzak, aluzyjnic przywolujący stowa Biblii, odwołuje się do zbiorowych emocji opartych na idei braterstwa stanu szlacheckiego "3it. Jęzkiem bojowej pobudki posługuje się królewski orator takze wtedy, gdy powoluje siç na „zwyklą przewaģ i męstwo doświadczone” rycerstwa i przeciwstawia mu pomniejszenic sił nieprzyjacielskich:

trwoży nieprzyjaciel, który barziej upomy niźli mężny, wątleją mury, które bàrziej pozorne niźli potężne [k. 2()1 $u^{\prime}$.]:

\footnotetext{
17. .Gdy już tak wojsko stançlo we sprawic, objezdzając pan lectman od hufu do hut in animowat swoich, ukazu-

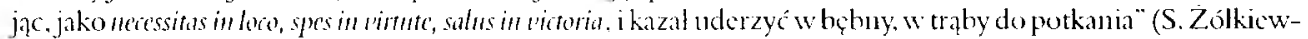

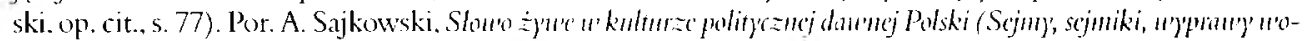

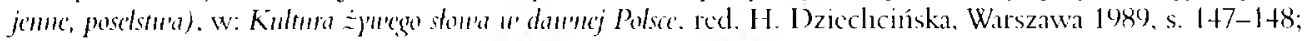

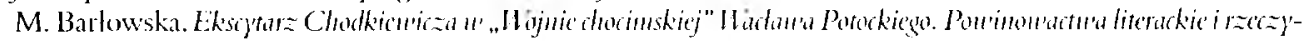
uriste, .Barok. Historia - Litcratura - Sztuka" 2(10)1. nr 1. s. 80).

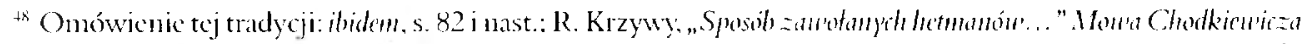

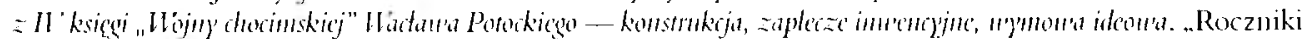

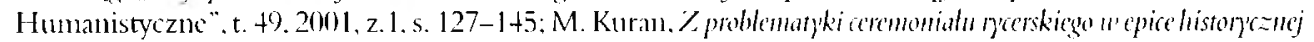

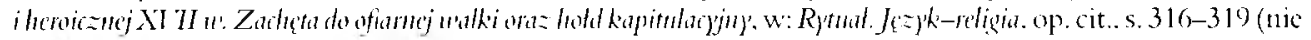

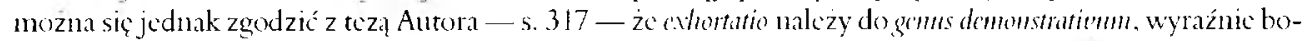

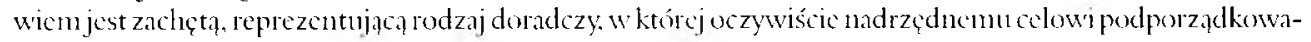
na jest topika pochwaly i magany).

14 Zob. J. Maciszcwski, op. cit.. s. 176.

5n Aluzja do biblijnych stów Boga do Kaina: ..Krew brata twego glośno wola ku muie z zieni!"” (Rdz t. I(I): Spranta Smolcriska.... op. cit.. s. 111.
} 
są wiadomości, ze i nieprzyjaciel nic tak, jako pokazuje, śmialy, i miejsce nie tak, jako się zda, straszne, sama rezolutia zwycięstwo w ręce poda [k. 202].

Argumentem zachęcającym do boju było wskazywanic korzyści, jakie on przyniesie. Były to przede wszystkim wzniosłe zapewnienia o slawie i dotrzymaniu wiemości przodkom, ale też ukazywanie czysto materialnego zysku w postaci czekających w obozic nieprzyjacielskim łupów. Szczególnie ten drugi sposób przekonywania zostal tu rozwinięty:

A nie zwycięstwo tylko, ale i daleko słynącą slawę narodom naszym przyniesie i w[asz]m[ościom spodziewanie korzyści, ponieważ stąd Ojczyźnie tylko a w[asz]m! oś]ciom wszystko w pożytek pójdzie. W[asz ]m[oś]ciów tych upornych ludzi dostatki czekają, rozszerzy siç ręka J[ego] K[rólewskiej] M[ósi] w rozszerzonych granicach, sporzej nagradzać będzie przeważne dziela w[asz]m[oś]ciów [k. 202].

Ekshortacja to mowa ze swej natury gwaltowna, majaca poruszyć silne cmocje i zmobilizować do działania wolę żolnierzy, co opisywano metaforycznie jako niecenie ognia w sercu słuchaczy. Temu służyło międ zy innymi ukazywanie momentu bitwy jako chwili decydującej o życiu i śmierci, ocaleniu bądź obronic podstawowych wartości. Na tym tle zdefiniowanie sytuacji przed smoleńskim szturmem wypada blado. Oto zapalić rycerzy do boju powinno zniechęcenie długim oczekiwaniem. To od powołania się na nie zaczyna się oracja:

Baczyć to J[ego] K[rólewska] M[oś]ć, nasz M[iłoś]ciwy Pan, wybornie raczy,

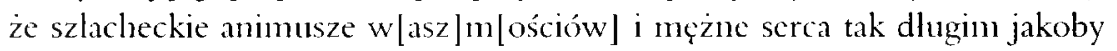
proznowaniem pod tymi murami obrzydzicly siç [k. 201-201 1 .].

I podobnież siç kończy:

Ząadać tedy i powtóre raczy, abyścic $w \mid$ asz $|\mathrm{m}|$ oś]c[iowic] to utesknienie swoje. które dotąd przy Jelg]o K[rólewskiej] M[oś]ci ponosiliście, ochotną mężnych rąk robotį i sobie, i Panu swemu nagrodzili [k. 202].

Wydaje się, że przypomnienie tych negatywnych przecież doświadczeń i związanych z nimi emocji niezbyt dobrze służy zagrzewaniı bojowego ducha. Na to osłabienie zdecydowanego tonu i gwaltowności towarzyszącej wezwaniom pobudkowym wplywa równiez obecność w adhortacji tlumaczeń i wyjaśnień, jakich wladca nawet w tym decydującym momencie nie skąpi swemu wojsku:

Lubo to ani z przyczyny urzędników J[ego] K[rólewskiej] M[ości] a pogotowiu nie z samego J[ego] K[rólewskicj] M[ości] poszlo, ale raczej za przypadajacymi konsyderacjami, za potrzebnymi traktatami, za napadającymi wiadomościami, a najwiecej oczekawając, aby ten uporny naród nad sobą się raczcj upamiętał, niźliby miał na ostrość szable polskiej przyjšć [k. $201 \%$ r.]. 
Na koniec dodane zostaje jeszcze jedno wyjaśnienie, które choć ozdobione zachętą, rozwija ten san, obcy ekshorcie ton tłmnaczeń. rozwiewających wątpliwości, na które w niej nic powinno być miejsca:

Podaje też i to J[ego] K[rólewsha] M[ość| do wiadomości w|asz]m[oś]ciów, wdzięcznie to czekanic przyjnując, któreście zołdu swego wytrwali, że zapłatę w[asz|m|ośjciom Pan Podskarbi Koronny nie tylko obmyślit, ale odliczyl, a nic

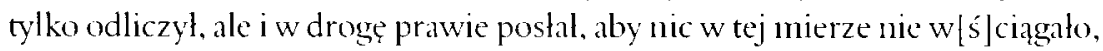
jeśliby co serce szlacheckie od widomej sławy cofać kicdy miało [k. 202].

Thumaczenic takies, raz jeszcze dowodzące zadomowienia się kwestii finansowych $w$ oficjalnym języku „rycerskicj słuzby”, osłabia wyraźnie pewność przckonania o wysokicj, duchowej jedynie motywacji rycerstwa, która miala być podstawowym wymiarem zachęty do boju.

Wą̧tpliwości może też budzić kreacja retorycznego podmiotu. Naturalną konsekwencją wypowiadania zachęty przez króla jest skomplikowanie sytuacji komunikacyjncj. Orator, mówiąc ,od J[ego] K[rólewskiej] M[ości|”, musi używać form trzeciej osoby. A towarzyszą jej jeszcze formy grzecznościowe. Stale powtarzanic zwrotu „J[ego] K[rólewska] Mość] raczy" ma podkreślać znaczenie woli samego monarchy, ale jednocześnie osłabia kategoryczność wypowiedzi. Król jako ostateczny nadawca zachęty do szturmu pozostaje osobą wpisaną w wyznaczoną monarsze rolę. On „wzywa”, „żąda”, obiecuje laskę, ale podczas bitwy „na to patrzać będzic". Role nadawcy i wodza są wiçc wyraźnic rozdziclone, nie adrestuje do wojska pobudki „zawołany hetman”, ale pozostający obok bezpośredniego starcia monarcha. Nie może więc zustać wykorzystana niezwykle ważna linia ekshortacyjnego dowodzenia: powolywanie się na whasny przykład i zapowiedź mężnej postawy w boju. Co prawda, sytuacja taka znana jest z literackich realizacji eksporty; na swoje wojska będzic patrzył i tym je zaclıęcal Wladysław IV w poenacie Twardowskiego czy Osman w Transakcji u'ojn)' docimskicj, ale na pewno jest to słabszy, pozbawiony istotnego elementu heroicznej konwencji wariant bojowej pobudki. W Adhortacyi... wymowç zachęcy osłabia coś jeszczec.

Żądać tedy Je[g]o K[rólewska] M[oś]ć i [od] w[asz]m[oś]ciów p[anów] pułkowników swych z rotmistrzami, i wszystkiego rycerstwa swego raczy, abyście w[asz]m[ościowie] na dzicń szturnowi naznaczony każdy wedlug serca szlacheckiego w oczach Je [gr]o K[rólewskiej] M[oś]ci, Pana swe [g]o, to pokazowal, czym by rad i w kronikacl, i " Pana swe[g]o wiecznie słynąt [k. 20) 2].

Mowa pobudzająca do boju powinna pojawić siç przed bitwą, to sytuacja tuż przed starciem wplywa przecież w decydujący sposób na jej charakter. Nie wiadomo, kiedy ostateczule Adhortacyja ... pod Smoleńskiem zostata wygłoszona. Pewne jest jedno, skoro mowa o „dniu szturmowi nazmaczonym”, nie bylo to tuz przed atakiem.

Szturm na Smoleńsk przcprowadzony 13 czerwca 1611 r., po niemal dwóch latach oblężenia twierdzy, okazal się w końcu skuteczny. Kończąc swój paniç̨nik, Stanisław Żólkicwski 
zapisał: „Podziękowawszy Panu Bogu, król jegomość zołnierzom też dziękowal” ${ }^{51}$. Ten krótki komentarz hetmana można uznać za podstawowy plan dyspozycji Dziçkou'ania ncerstu'u po uzięciu Smoleniska. We wstępnej części swego wystapienia podkanclerzy Kryski rozwinąl bowiem myśl o Bożej wszechmocy, której jawnym dowodem jest zdobycie Smoleńska. Kolejny też raz, nawiązując do mowy Jakuba Potockiego, uznal zwycięstwo Zygmunta III za dowód sprawiedliwości i sprzyjania Bozej Opatrzności:

czym jaśnic pokazal i sprawiedliwość Ojczyzny naszej i szczyrość J[ego] K[rólewskiej] M[oś]ci, którą Rz[ecz|p/ospo]lita idzie, że wlości zdradą przodkom J[ego] K[rólewskiej] M[ości] odjęte nie przy hospodarach moskiewskich z traktatów, ale przy królach polshich przez miecz mieć chiciał. Jemu tedy jako w[asz]moś]c[iowie] słusznie przypisujecie, tak J[ego] K[rólewska] M[ość] winne dzięki oddawać raczy, że i możności swej w osobie J[ego] K[rólewskiej] $\mathrm{M}$ [ości] przykład na świat podal, i dufającego sobic blogoslawić raczyl pomazańca swego ${ }^{52}$.

Natomiast drugą część swẹj mowy poświęcil pochwale rycerstwa, podkreślając, że złożylo ono dowody męstwa „w oczach pana swego". W tym też miejscu ujawnil cały oratorski kunszt, wyliczając rzeczy i czyny (anafory zawienajace czasowniki dokonane) nzyskal dobitność relacji, a wprowadzając pominięcie i sumująca percursio, zasugerowat nieograniczoność pocliwaly:

Ale i W[asz]m[oś|c|iów] przy tym picczolowanie, praca, przemysl, przewaga, męstwo godne i przystojnej od pana swego wdziçczności. Wytrwaliście teskliwy na jednym micjscu przy panie swym nicwczas, przetrwaliście upornego nieprzyjaciela, a przetrwaliście go nie tym, abyście go wyglodzić mieli, ale niepodobną rąk swoich robota. Doszliście niestrwożonymi sercami swymi wysokich, gładko murowanych oblanków, wysadziliścic subtelnym przenystem, w których oni ufali, mury, opakowaliścic żywa siłą glęboko rzucone waly. A czyniliście to w oczach pana swego tak ochotnie, że przodku uznać trudno miat, ojeden raz wodzowie, o jeden raz towarzystwo, ojeden raz wszyscy sławy pana swego mężnie dźwigali. Prózno szerzyć, niechaj największy nieprzyjaciel J[ego] K[rólewskiej] M[ości] i narodów naszych pojrzy, pozna po sprawie, co i jakiego serca ludzie robili. Ja śmiele rzekę, żeścic odważne mózgi odwagą uporną serca, męstwem znieśli upornym [k. $46 \%$.].

Zapewnieniom o królewskiej lasce i nagrodach dla zdobywców Smoleńska towarzyszyly jeszcze dwie indywidualıe pochwały. Picrwsza z nich dotyczyła kawalera maltańskiego, Bartomicja Nowodworskiego, którego zasług w walkach o miasto nie „przepomniała” chyba

s. S. Zólkicwski. op. cit.. s. 118.
s2 Rps BK.324. k. 46 ". 
zadna relacja ${ }^{53}$. W drugiej, wśród tych, co odnicśli rany i którym król obiccywat swą opiekę, przypomniany zostat Gorecki, rotmistrz w pulku Aleksandra Zborowskicgo, śmiertehnic ranny podczas ostatniego szturmust.

Dziękowanie od króla rycerstwu pod Smoteńskiem by to ściśle związane z ceremonią holdı pokonanych obrońców miasta. Slad tego związku pozostal w oracji:

Wdzięcznie tedy Jlego] K[rólewskal M[ość], Pan nasz Miłościwy to przyjnować od W[asz] m[ościów raczy: sprawę porządną od tych, którym ta impreza zlecona byla, męstwo od rycerstwa, a spólıie od wszystkich korzyść dzielności. Przyjmuje te żywe dzieła W|asz |m|ościów] hupy: archiepiskopa glowę tych tutecznych kościotow, wojewody a uporneggo odważnych oblezzeńców wodza, ktotki otwarte, zamek wolny i niepodobne do dobycia mury [k. $46 \mathrm{l}$.].

Uroczystość ta byla jedynie początiem propagandowego wyzyskania zdobycia Smoleńska jako tryumfu Zygnumuta III. Sceny oddawania jeńców miały w tej kreacji króla niebagatelne znaczenic. W Zanku Królewskim w sali senatu znalazły siç̨ dwa wielkie malowidła historyczne Tomasza Dolabelli. Jedno przedstawialo w postaci kronikarsko ujętej zbiorowej sceny zdobycic Smoleníska, drugie - przedstawione ad atr'mu" oddawanie Szujskich na sejmie 35 .

Dopehnieniom obrazu oratorstwa z obozu pod Smoleńskiem powinny być dość liczne mowy zalobne. Jednak tylko jedna, mowa po śmierci Jana Potockiego, wojcwody braclawskiego została ściśle określona: „do J[ego] K[rólewskiej] M[ości] pod Smolerískiem”. Jest to jednak oracja, którą trudno przypisać do jakiejś znancj odniany oratorstwa pogrzebowego. Zostala ona wygłoszona przez Feliksa Kryskiego jako przyjaciela rodziny w innieniu pozostałych Potockich. Wypelnia ją typowe dla nów żałobnych połączenie opłakiwania i pochwaly, w której zmarły dowódca został przedstawiony przede wszystkim jako wierny do końca sługa króla, alè i zotnierz:

Na mizermą deszczkę nieużyta śmierć wzięła go, zģwałciwszy potęgę i nieszanującego się żolnierza, odważnego pułkownika i przeważnego wodza. Nie darmo powiadają, ze tuczna, bo w źrzeniç ugadza, nie darmo bujna, bo i potrzebon monarchów nie wygadza "at".

Jednak zakończenie mowy, skierowane wprost do wladcy, jest raczej uroczyścic składaną obietnicą, że krewni będą szli ,jego gościncen". Być może więc najważniejsze są ostatnie slowa, będące także istotną deklaracja polityczną:

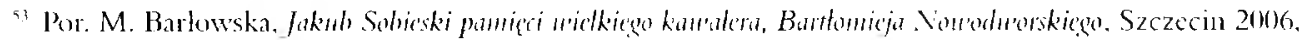
s. 12.

it ..Chcial byl pan Gorccki rotmistrz. który tam z pancm starostz̨ félińskim byl. kusić siç; ale sposobu nic bylo wejscia. I san ten rotnistrz (jorecki tan postrzelon. Jedem tylko Moskwicin wystrzelil i od tego postrzalu umarl" (S. Żílkicwski. op. cit.. s. I I8).

${ }^{4}$ Zob. W. Tomkicwicz, Doldalla. Warszawa 1959. s. 18-19.

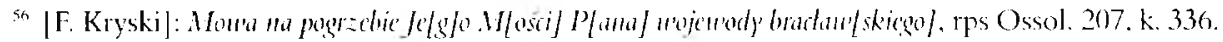


Ostatek hasce W[aszej] K[rólewskiej] M[ości] i uważnemu baczeniu wrodzonej dobrotliwości poruczając, sami sicbie z tym wszystkim, co milszego mają i ono grono rycerstwa zawszc pod regimentem i choragwiąjego R[zeczypospolitej] i W[aszej] K[rólewskiej] M[ości] słuzące mi toś]ciwej i powinncj ochronie W[aszej] K[rólewskiej] M[ósici] oddają [k. 336 u.].

Jak wiadomo, po odjeździe hetmana Żólkiewskiego dowództwo objąl brat zmarłego, Jakub Potocki. Okoliczność wyrażenia żalu po zmarłym mogła więc być okazją do oficjalnego zadeklarowania dalszego trwania u boku króla.

Typowa sytuacją, którcj w obozic towarzyszyły mowy żałobne, bylo uroczyste wyprowadzanic cial zmarłych rycerzy. Uczestnikom ceremonii nalezalo się w takich okolicznościach choćby podziękowanie od rodziny. Zapewne liczniejsze przemowy towarzyszyły eksportacji do Ojczyzny ciała księcia Romana Rożyńskiego, 21 czerwca 1610 roku:

Które nazajutrz do Polski honorifice i dość pompose wyprowadzono, bo też KJM przez posta swego, JM pana podkinclerzego koromnego ten akt uhonestować [kondekerować] raczyl, a JM panowie senatorowie, rotmistrzowie i znaczne rycerstwo gromadą aż za obóz wyprowadzili"

Nie udało się jednak odnaleźć nawet tej wygłoszonej przez Kryskiego mowy. Pod Carowym Zamieściem zginąl Marcin Wejher:

Ten bywszy nabożnym tegoż dnia i zabiwszy kilku na harcach, z działa w jagodę postrzelon zarazem umarl i ciała dostać nie mozono, bo pod samą bramç ich podjachat bet ${ }^{56}$.

Ciało jego odzyskano dopiero po kilku tygodniach, po zdobyciu gródka ${ }^{53}$ i 27 października 1609 r. „do Polski z obozu wyprowadzono "*. Dopiero z pogrzebu zachowała się mowa Feliksa Kryskiego przy wyprowadzeniu ciała z podziçkowaniem od braci, którzy „żalosny, ale sławny zllak swego męstwa do domu odwożą, „¿eście się nie lenili za niepotrzebnym prochem towarzysza swego iść". Z kolei w heroicznej, poetyckiej wizji Kaspra Miaskowskiego zapisana została droga do Ojczyzny Wojciecha Gajewskiego, którego „w szańcach nieopatrznie stojącego, z hakownice w gardlo postrzelono, ze na tym placu zostal i skonal" i którego cialo wyprowadzono z obozu dziesięć dni później, 27 października 1609 roku" . Poświęcone pamięci rycerza oracje zachowały siç tylko z pogrzebu w Poznaniu: Na pogrzebic P[ana] Wojciecha

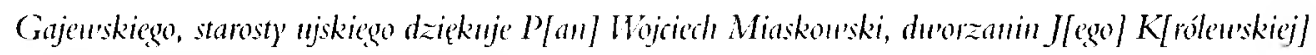

\footnotetext{
37 Diarius: drogi ..., s. 150 .

"5x Ibidcm, [Wiadomości spod Smolcíska]. s. 252-253.

M. S. Marchocki, op. cit., s. I01.

(x) Diarias: drogi.... s. 88 .

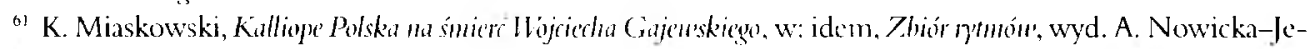

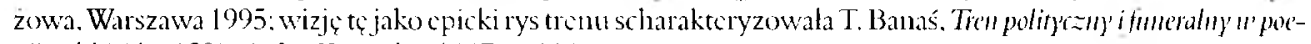
zi polskicj lat 1580-1630, Katowice 1997, s. 114.
} 


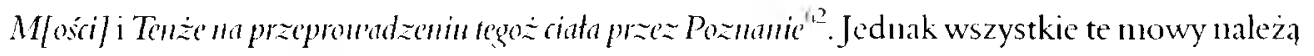
nie do sceny wojenncj pod Smoleńskiem, lecz rozgrywającego się już zupelnic gdzie indziej, pogrzebowego theatrmm, na którym długo jeszcze po zakończeniu walk pojawialy się wspomnienia tego epizodu wojny moskiewskicj, przywolywane przy okazji gloszonych nad grobem pochwal ludzi kiedyś w niej uczestniczących.

Jak w każdym badaniunowej sprawy, przywohując w sukurs odwieczne zalecenia retoryki, trzeba się na razie zadowolić odpowiedzią twierdzącą na pytanie o samo istnienie faktu, czyli potwierdzeniem funkcjonowania oratorstwa na wojennym thentrum. Rozważenic dalszych kwestii, pytań o jego definicję i oceny, traktując jedynie jako rysujące się perspektywy badawcze. Perspektywy, w których trzeba będzie uwzględnić jedno stwierdzenie: oratorstwo jako pierwszy dokument reagowania na zdarzenia i ich opisywania jest nieodhączną częścią całego publicznego dyskursu z tych burzliwych czasów.

62 Rps Litewskiego Państwowego Archiwum I listoryctnego 1135, op. 2/40. k. 81 1"-83. 